\title{
Ultrasonography for measuring rectus abdominis muscles diastasis ${ }^{1}$
}

\author{
Ultra-sonografia para medir a diástase dos músculos retos do abdome
}

\author{
Denise de Almeida Mendes², Fábio Xerfan Nahas ${ }^{3}$, Daniela Francescato Veiga ${ }^{4}$, Fernando Vilela Mendes ${ }^{5}$, Ricardo \\ Góes Figueiras $^{6}$, Heitor Carvalho Gomes ${ }^{7}$, Pedro Bins Ely ${ }^{8}$, Neil Ferreira Novo ${ }^{9}$ Lydia Masako Ferreira ${ }^{10}$ \\ 1. Study performed at Plastic Surgery Division, Surgery Department, University of Vale do Sapucai (UNIVAS), Pouso Alegre, Minas Gerais, Brazil. \\ 2. Fellow Master degree, Interinstitucional Masters Program, Federal University of São Paulo (UNIFESP) and UNIVAS, Brazil. \\ 3. PhD, Associate Professor, Plastic Surgery Division, Surgery Department, UNIFESP, São Paulo, Brazil \\ 4. PhD, Associate Professor, Plastic Surgery Division, Surgery Department, UNIVAS, Pouso Alegre, Minas Gerais, Brazil. \\ 5. MD, Minas Center of Mastology and Imaging, Pouso Alegre, Minas Gerais, Brazil. \\ 6. MD, Resident, Plastic Division, Surgery Department, UNIVAS, Pouso Alegre, Minas Gerais, Brazil. \\ 7. PhD, Assistant Professor, Plastic Surgery, UNIFESP, São Paulo, Brazil. \\ 8. PhD, Preceptor Plastic Surgery Unit Santa Casa Porto Alegre, Rio Grande do Sul, Brazil. \\ 9. PhD, Associate Professor, Biostatistics Department, UNIFESP, São Paulo, Brazil. \\ 10. Full Professor, Head, Plastic Surgery Division, UNIFESP, São Paulo, Brazil.
}

\begin{abstract}
Purpose: Preoperative imaging evaluation may be useful for determining the position of recti abdominis muscles before their correction. The purpose of this study is to evaluate the accuracy of ultrasonography to measure the width of rectus abdominis muscle diastasis. Methods: Rectus diastasis was measured by ultrasonography preoperatively in 20 females. Rectus diastasis was measured in seven levels along the anterior rectus sheath by ultrasound after sustained deep inspiration and after expiration. Rectus diastasis, at the same levels, was also measured after its exposition during abdominoplasty by two independent observers, using a surgical compass. These values were compared using Wilcoxon's statistical text, for non independent values. Results: There was no significant difference between the values obtained by ultrasound and those measured during surgery in the supra-umbilical levels and at the level of the umbilicus. However, below the umbilicus these values differed significantly, showing smaller values in the imaging evaluation. Conclusion: Ultrasonography is an accurate method to measure rectus diastasis above the umbilicus and at the umbilical level.
\end{abstract}

Key words: Abdominal Wall. Abdominal Muscles. Ultrasonography. Diagnostic Imaging. Surgery, Plastic. Rectus Abdominis.

\section{RESUMO}

Objetivo: Estudos radiológicos pré-operatórios podem ser úteis para determinar a posição dos músculos retos do abdome antes de sua correção. O objetivo deste estudo é avaliar a acurácia da ultra-sonografia para medir a largura da diástase dos músculos retos do abdome. Métodos: A diástase dos músculos retos foi medida pela ultra-sonografia, no pré-operatório em 20 mulheres. A diástase dos retos foi medida em sete níveis da bainha anterior dos retos foram examinados com ultrasom após inspiração profunda sustentada e após expiração. A diástase dos retos, nos mesmos níveis, foi também medida após sua exposição durante a abdominoplastia, por dois observadores independentes, usando compasso cirúrgico. As medidas foram comparadas usando o teste estatístico de Wilcoxon para dados não independentes. Resultados: Não houve diferença significante entre as medidas ultra-sonográficas e intra-operatórias nos níveis supra-umbilicais e na cicatriz umbilical. Todavia, inferiormente à cicatriz umbilical, essas medidas diferiram significantemente sendo as ultrasonográficas menores nestes pontos. Conclusão: A ultra-sonografia é um método acurado para medir a diástase de retos na região supra- umbilical e no nível do umbigo.

Descritores: Parede Abdominal. Músculos Abdominais. Ultra-sonografia. Diagnóstico por Imagem. Cirurgia Plástica. Reto do Abdome. 


\section{Introduction}

Rectus diastasis is one of the anatomic conditions that may lead to the anterior projection the abdominal wall. Functional problems, such as back pain and hernia, may also occur due to this condition ${ }^{1,2}$. As the recti muscles are superficially positioned, in most cases, rectus diastasis is easily evaluated, and a correct diagnosis can be done based on the medical history and physical examination. However, when the subcutaneous fat is thick and when there is a large abdominal laxity, palpation of the diastasis may be difficult. This condition associated with a wide rectus diastasis, increases the risk of abdominal wall perforation when liposuction is performed. Therefore, in such cases, imaging of the muscles of the anterior abdominal wall may be indicated. Historically, Birdsell ${ }^{3}$ and Netscher ${ }^{4}$ utilized metal markers and serial radiographies to verify rectus diastasis correction. Nowadays, computed tomography is considered the method of choice to examine the abdominal wall, but it is expensive and also exposes the patient to radiation risks ${ }^{5-8}$. Ultrasonography has been proposed as a non invasive technique that may be repeated several times. It is used for the diagnosis of hernias, quantification of intra-abdominal fat and to diagnose abdominal wall relaxation ${ }^{9-11}$. Ultrasound has also been used to access long term durability of rectus sheath repair ${ }^{11}$. On the other hand, a correct evaluation depends on the examiner training, the quality of the image may be harmed by interposed fat and fibrosis and ultrasound has a small field of view as compared to computed tomography or magnetic resonance imaging. The present blinded study aimed to evaluate the accuracy of ultrasonography to measure the width of rectus abdominis muscle diastasis.

\section{Methods}

Twenty consecutive patients, who presented abdominal wall deformity, were evaluated at University Hospital Samuel Libânio, from July 2005 to February 2006. Nineteen of the twenty patients have had a previous cesarean section. All of these patients underwent both a preoperative ultrasonography of their anterior rectus abdominis sheath to evaluate the width of rectus diastasis and an intraoperative surgical measurement of the diastasis. Seven measurements points were established: 3, 6, 9 and $12 \mathrm{~cm}$ above the superior margin of the umbilicus, 2 and $4 \mathrm{~cm}$ below its inferior margin and also at the umbilical level. The ultrasonographic evaluation was done in all patients using the same device (Medson Sonoace 8000, Korea, high frequency transducer) by a ultrasonographist, in situations of sustained maximum inspiration and expiration. Intraoperative measurements were obtained by 2 independent observers, with a surgical compass.
The average between the inspiratory and expiratory measurements of rectus diastasis obtained by ultrasound evaluation was used to compare with intra-operative values. Abdominoplasty was performed under epidural anesthesia through a suprapubic incision, extended laterally to both anterior iliac crests. The abdominal cutaneous flap was dissected from the aponeurosis. The superior limits of the dissection were the costal margins and a level $2 \mathrm{~cm}$ above the xyphoid appendix. The midline was marked with blue ink, as were the levels of the diastasis studied. The widths of rectus diastasis were measured by both the surgeon and by the assistant, in a blinded fashion (Figure 1). The values obtained by the two observers were compared using Wilcoxon's text. Rectus abdominis diastasis was then corrected by plication of the anterior rectus aponeurosis, with polipropylene, in a two layers fashion: the first layer with triangular mattress sutures with interrupted buried stitches ( $0.4 \mathrm{~cm}$ from each other) and a second layer with a continuous suture. Excess tissue was ressected and the circumcised umbilical stalk was pulled through the flap. Quilting sutures were done attaching the abdominal flap to the aponeurosis ${ }^{13}$. The patients were allowed to walk 24 hours after the operation and were discharged at the second postoperative day. The average between the inspiratory and expiratory measurements of rectus diastasis obtained by the ultrasound evaluation were compared to the average of intraoperative values using Wilcoxon's test.

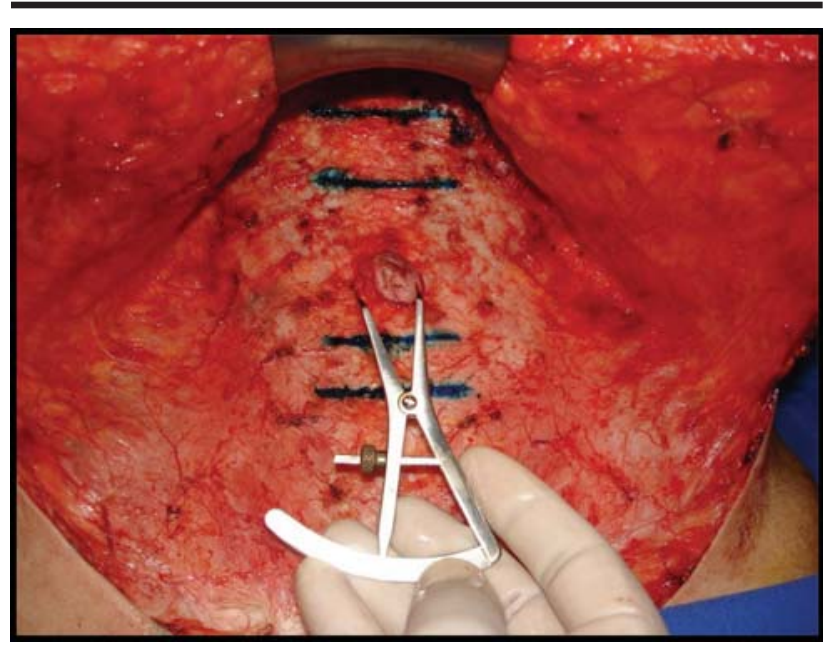

FIGURE 1 - Intraoperative measurement

\section{Results}

There was no statistical significant difference when the values of rectus diastase measured by the surgeon and by the assistant using the surgical compass (Table 1). There was no statistical significant difference when the average values of rectus diastase obtained by ultrasound were compared to the intra-operative values at the supra umbilical (Figure 2) and umbilical levels; 
however, significantly higher values were found during The values can be seen in Table 2 . surgery in the infra-umbilical levels (Figure 3).

TABLE 1 - Average of values of rectus diastasis, according to the level studied, having the umbilicus as reference, by 2 independent observers using the surgical compass

\begin{tabular}{lcccc}
\hline Level (cm) & $\begin{array}{c}\text { IO Surgeon } \\
(\mathbf{m m})\end{array}$ & $\begin{array}{c}\text { IO Assistant } \\
(\mathbf{m m})\end{array}$ & $\begin{array}{c}\text { Wilcoxon's } \\
\text { test z }\end{array}$ & $\mathbf{P}$ \\
\hline S-U 9 & 15,2 & 13,8 & 1,35 & 0,08 \\
S-U 6 & 19,9 & 19,9 & 0,33 & 0,37 \\
S-U 3 & 23,5 & 24,6 & 0,78 & 0,21 \\
Umbilicus & 25,8 & 26,8 & 1,24 & 0,40 \\
I-U 2 & 17,5 & 16,5 & 0,78 & 0,21 \\
I-U 4 & 13,7 & 12,1 & 1,18 & 0,11 \\
\hline
\end{tabular}

IO Surgeon = intraoperative values measured by the surgeon

IO Assistant =intraoperative values measured by the assistant $\mathrm{S}-\mathrm{U}=$ supra-umbilical

$\mathrm{I}-\mathrm{U}=$ infra-umbilical

TABLE 2 - Average values for rectus diastasis, according to the level studied, having the umbilicus as reference

\begin{tabular}{lcccc}
\hline Level (cm) & $\begin{array}{c}\text { US average } \\
(\mathbf{m m})\end{array}$ & $\begin{array}{c}\text { IO average } \\
(\mathbf{m m})\end{array}$ & $\begin{array}{c}\text { Wilcoxon } \\
\text { text } \mathbf{z}\end{array}$ & $\mathbf{P}$ \\
\hline S-U 12 & 8,8 & 9,9 & 0,40 & 0,3446 \\
S-U 9 & 14,8 & 14,4 & 0,11 & 0,2946 \\
S-U 6 & 18,5 & 20,0 & 1,13 & 0,1292 \\
S-U 3 & 23,9 & 24,5 & 0,54 & 0,4562 \\
Umbilicus & 26,7 & 26,1 & 0,52 & 0,3015 \\
I-U 2 & 11,6 & 17,0 & $2,80^{*}$ & 0,0029 \\
I-U 4 & 7,4 & 12,9 & $2,92 *$ & 0,0018 \\
\hline
\end{tabular}

US = ultrasonographic

$\mathrm{IO}=$ intraoperative

$\mathrm{S}-\mathrm{U}=$ supra-umbilical

$\mathrm{I}-\mathrm{U}=$ infra-umbilical

* Statistically significant values

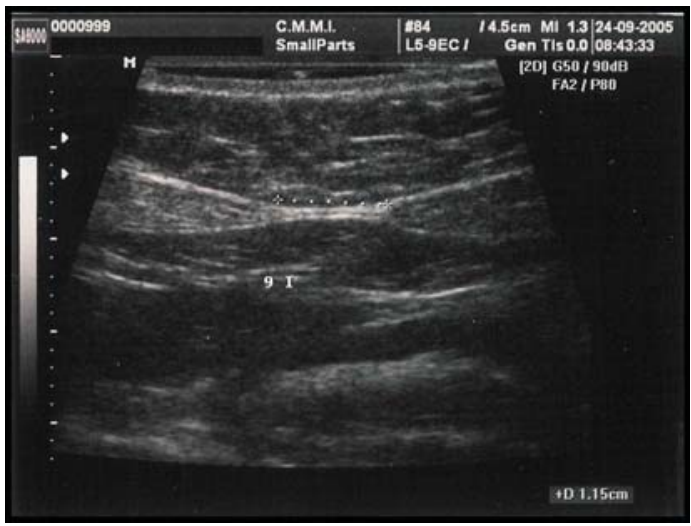

FIGURE 2 - Ultrasonographic image at supra umbilical level, showing a good visualization of rectus sheath which is highly echogenic as compared to the mainly hipoechoic muscle. The cursor shows the medial limit of recti abdominis muscles.

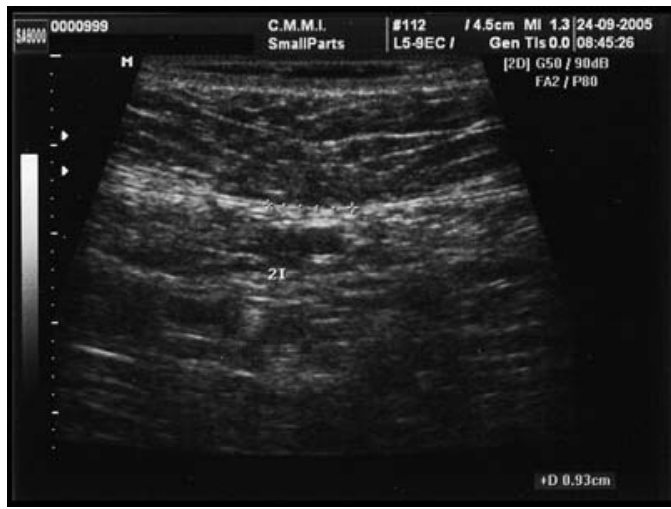

FIGURE 3 - Ultrasonographic image at infra-umbilical level, showing the loss of definition of the posterior layer of recti muscles. Therefore, it is difficult to measure recti diastasis. 


\section{Discussion}

Correction of rectus abdominis diastasis has been done since the original description of abdominoplasty ${ }^{14}$. In most cases, rectus diastasis occurs after pregnancy or major weight loss. Correction is achieved by plication of the anterior rectus sheath. In some cases, these muscles may present abnormal insertions in the costal margins, making it necessary to open the rectus sheath, to undermining the rectus muscles and to suture them in the midline for its correction ${ }^{15,16}$. Therefore, pre-operative diagnosis of this deformity may be necessary. Determination of the abdominal wall integrity is also important before an abdominal lipoaspiration, because intestinal perforations may occur in the presence of undiagnosed preoperative defects ${ }^{17}$. These defects are usually located in the area between the umbilicus and the xyphoid. Computerized tomography is a good method to determine the position of rectus muscles, but it is expensive and exposes patients to radiation. Ultrasonography is a simpler and less expensive alternative to measure rectus diastasis. It enables maneuvers such as increasing the intra-abdominal pressure and changing the patient's position, what can be helpful in the detection of hernias. It is a dynamic exam that depends on the examiner's skill. Nevertheless, subcutaneous interposition and fibrosis may interfere in the precision of ultrasonographic imaging. The small field of view in conventional ultrasonography, which is limited to the width of the transducer (in general about 4 to $6 \mathrm{~cm}$ ) may decrease the exam accuracy. Sophisticated technologies were developed to minimize ultrasonographic limitations, but they aren't always available. One example of these sophisticated technologies is the extended field of view ultrasonography on which computer softerwares are used to combine the obtained images. Another example is the use of echoes filters, which produce tissue harmonic imaging. By using a Gaussian shaped transmitted pulse it is possible to separate from the returning echo the harmonic component without overlapping with fundamental reflections. The improved image quality leads to higher diagnostic confidence ${ }^{18,19}$. These technologies can be used simultaneously. Every patient studied had a previous pregnancy and most of them have had a c-section. Therefore, this is a representative group of typical patients that undergo abdominoplasty. The exams were done along the whole length of the rectus muscle and were registered at regular intervals. The average between the widths of diastasis during inspiration and expiration in ultrasound evaluation was used to achieve a neutral position. This neutral position simulates the intra-operative position of the recti muscles when the patient is under epidural anesthesia. The values obtained during surgery were taken by two independent observers. As the muscle's position is evaluated through the rectus sheath, the observers could have measured the diastasis differently. This can happen in patients that present thin muscles covered by a thick aponeurosis. In such patients, differences in the intra-operative measurement may occur because it may be difficult to identify the medial margins of the recti muscles. However, there was no statistical significant difference between the two observator's values in this study, and the average of these values was used. It is possible that the differences between intraoperative and ultrasonographics measures below the umbilicus occurred due to the presence of fibrosis resulting from previous cesarean section, since 19 out of the 20 patients had been previously undergone this procedure. Only one study found a small difference between the intraoperative measurement measures and the values obtained using CT-scan ${ }^{20}$. More studies are necessary to show if the difference bellow umbilicus was due to examiner technical difficulty or due to the imaging method used. If it is the second case, it is necessary to find out if the fibrosis is more deleterious to the precision of ultrasonography or CT-scan in diagnosing the position of the muscles of the abdominal wall. In conclusion, the ultrasound is a reliable method to evaluate rectus diastasis at the umbilical and at the supraumbilical areas.

\section{Conclusion}

Ultrasonography is an accurate method to measure rectus diastasis above the umbilicus and at the umbilical level.

\section{Refererences}

1. Toranto IR. Resolution of back pain with the wide abdominal rectus plication abdominoplasty. Plast Reconstr Surg. 1988; 81(5):777-9.

2. Gireev GI, Zagirov UZ, Shakhnazarov AM. Treatment of linea alba hernia and diastasis of rectus abdominis. Khirurgiia (Mosk). 1997; (7): 58-61.

3. Birdsell DC, Gavelin GE, Kenmsley GM, Hein KS. "Staiying power": Absorbable vs no absorbable. Plast Reconstr Surg. 1981; 68(5): 742-5.

4. Netscher DT, Wigoda P, Spira M, Peltier M. Musculoaponeurotic plication in abdominoplasty: how durable are its effects? Aesth Plast Surg. 1995; 19:531-4.

5. Rath AM, Attali P, Dumas JL, Goldlust D, Zhang J, Chevrel JP. The abdominal linea Alba: an anatomoradiologic and biomechanical study. Surg Radiol Anat. 1996; 18(4): 281-8.

6. Nahas FX. Should diastasis recti be correted? Aesth Plast Surg. 1997; 21(4): 285-9. 
7. Nahas FX, Ferreira LM, Augusto SM, Ghelfond C. Long term follow- up of correction of rectus diastasis. Plast Reconstr Surg. 2005; 115(6): 1736-41.

8. Lockwood D, Einstein D, Davros W. Diagnostic imaging: Radiation dose and patients's concerns. Cleve Clin J Med. 2006; 73(6): 583-6.

9. Toms AP, Charlote CJ, Cash BF, Freeman AH. Abdominal wall hernias: a cross sectional pictorial review. Semin Ultrasound CT MR. 2002; 23(2): 143-55.

10. Radomanski, RB, Vezozo D, Cerri GG, Halpern A. Ultrasound use in abdominal fat distribution evaluation. Arq Bras Endocrinol Metab. 2000; 44(1): 5-12.

11. Muller M, Truong SN, Shumpelick V. Sonographic diagnosis of abdominal wall relaxation. J Clin Ultrasound. 1999; 27(4): 183-6.

12. Uchelen J H, Kon, M, Werker, PMN. The long-term durability of plication of the anterior rectus sheath assessed by ultrasonography. Plast Reconstr Surg. 2001; 107(6): 1578-83.

13. Baroudi R, Ferreira CAA. Seroma: how to avoid it and treat it. Aesth Surg J. 1998; 18: 439.

14. Pitanguy I. Abdominoplastias. Hospital. 1967; 71 (6): 1541-56.
15. Nahas, FX. An aesthetic classification of the abdomen based on the myoaponeurotic layer. Plast Reconstr Surg. 2001; 108 (6): 1787-95.

16. Nahas FX, Ferreira LM, Mendes JA. An efficient way to correct recurrent rectus diastasis. Aesth Plast Surg. 2004; 28(4): 189-96.

17. Ovrebo KK, Grong K, Vindenes H. Small intestinal perforation and peritonitis after abdominal suction lipoplasty. Ann Plast Surg. 1997; 38(6): 642-4.

18. Schoelgens $C$. Improved b-image diagnosis with harmonic imaging. Ultrascall Med.1998; 19(5): M70-5.

19. Weng L, Tirumalai A, Lowery CM, Nock LF, Gustafson DE, Behren PL, Kim JH. US extendedfield of view imaging technology. Radiology. 1997; 203: 877-80.

20. Nahas FX, Augusto SM, Ghelfond C. Nylon versus Polydioxanone in the correction of rectus diastasis. Plast Reconstr Surg. 2001; 107 (3): 700-6.

\section{Acknowledgments}

To Dr. Guilherme Marques Ribeiro, Diretor of Departament of Imagem of Centro Mineiro de Mastologia e Imagem, where the ultrasonografic exams were made.

\section{Correspondence:}

Fabio Xerfan Nahas

Disciplina de Cirurgia Plástica / Departamento de Cirurgia

Universidade Federal de São Paulo (UNIFESP - EPM)

Rua Napoleão de Barros, 715/4 ${ }^{\circ}$ andar

04024-900 São Paulo - SP Brazil

Phone: (55 11)5576-4118

fabionahas@uol.com.br
Conflict of interest: none Financial source: none

Received: January 16, 2007 Review: February 14, 2007 Accepted: March 15, 2007

\section{How to cite this article}

Mendes DA, Nahas FX, Veiga DF, Mendes FV, Figueiras RG, Gomes HC, Ely PB, Novo NF, Ferreira LM. Ultrasonography for measuring rectus abdominis muscles diastasis. Acta Cir Bras. [serial on the Internet] 2007 May-June;22(3). Available from URL: http://www.scielo.br/acb 